\title{
Hemicriconemoides macrodorus n. sp. with observations on two other species of the genus (Nematoda: Criconematidae)
}

\author{
Nicola Vovlas ${ }^{1, *}$, Alberto TrocCOLI ${ }^{1}$ and Pablo CASTILlO ${ }^{2}$ \\ ${ }^{1}$ Istituto di Nematologia Agraria, Consiglio Nazionale delle Ricerche (CNR), Via Amendola 165/A, 70126 Bari, Italy \\ ${ }^{2}$ Instituto de Agricultura Sostenible Consejo Superior de Investigaciones Científicas (CSIC), Apto. 4084, Cordóba, Spain
}

Accepted for publication: 6 January 2000

Summary - Hemicriconemoides macrodorus $\mathrm{n}$. sp. is described and illustrated from a bisexual population collected in a natural habitat at Santa Elena, Jaén, southern Spain. The new species falls into the 'group 2', based on lip patterns (Decraemer \& Geraert, 1992), which contains 13 other species characterised by a cephalic region with an offset, raised, narrower oral disc, followed by broader head annuli. The main distinctive characters of the new species are: lip region truncate, very long stylet (90-100 $\mu \mathrm{m}$ ), long body 548-750 $\mu \mathrm{m}, \mathrm{R}=$ 127-148, conical tail, $\mathrm{VL} / \mathrm{VB}=1.0-1.5$, spined juvenile cuticular ornamentation (multispined scales, indented at their edges) arranged in ten alternate rows, and male lateral field with four incisures. Morphometric data, illustrations and brief descriptions are presented for an Italian population of $H$. ortonwilliamsi Ye \& Siddiqi, 1994, while, for the first time, morphometric data and illustrations are given for the male and the juvenile of $H$. alexis Vovlas, 1980.

Résumé - Hemicriconemoides macrodorus $n$. sp. et observations sur deux autres espèces du genre (Nematoda: Criconematidae) - Hemicriconemoides macrodorus n. sp. est décrit et figuré d'une population bisexuelle collectée dans un habitat naturel à Santa Elena, Jaén, le Sud d'Espagne. La nouvelle espèce appartient au "groupe 2" sur la base de la morphologie labiale (Decraemer \& Geraert, 1992), groupe comptant 13 autres espèces caractérisées par une région céphalique avec un disque labial séparé du reste du corps, proéminent et rétréci, suivi des anneaux céphaliques plus larges. Les principaux caractères distinctifs de la nouvelle espèce sont: région labiale tronquée, très long stylet (90-100 $\mu \mathrm{m})$, corps long 548-750 $\mu \mathrm{m}, \mathrm{R}=127-148$, queue conique, VL/VB $=1.0-$ 1.5, ornementations cuticulaires des juvéniles avec épines (écailles avec plusieurs épines, indentées sur les côtés) arrangées en dix rangées alternées, et champ latéral du mâle comportant quatre incisures. Des données morphométriques, des illustrations et de brèves descriptions sont présentées pour une population italienne de H. ortonwilliamsi Ye \& Siddiqi, 1994, alors que, pour la première fois, des données morphométriques et des illustrations sont produites pour le mâle et les juvéniles de H. alexis Vovlas, 1980.

Keywords - Greece, Hemicriconemoides alexis, H. ortonwilliamsi, Italy, morphology, Spain.

The genus Hemicriconemoides was erected by Chitwood and Birchfield in 1957. In 1991, Ebsary listed 38 valid species and, at present, 42 species are included in the genus, divided into five groups depending on the type of lip region structure (Decraemer \& Geraert, 1992; Rahaman \& Ahmad, 1995).

Specimens of a bisexual population characterised by a truncate lip region and a long stylet (about $100 \mu \mathrm{m}$ ) were found among plant parasitic nematodes extracted from soil samples collected during extensive collections in agricultural areas and natural habitats in southern Spain. Observations with light and scanning electron microscopy (SEM) indicated that our specimens should be assigned to a new species, in 'group 2' of Decraemer and Geraert
(1992). This new taxon is described as Hemicriconemoides macrodorus $\mathrm{n}$. $\mathrm{sp}$.

Representative populations for each of the other two species described herein (H. alexis Vovlas, 1980, from the type locality, and $H$. ortonwilliamsi Ye \& Siddiqi, 1994, collected in southern Italy) were used for the first description of males of $H$. alexis and for additional morphological data for H. ortonwilliamsi.

\section{Material and methods}

The three populations used in this study were extracted from soil samples by magnesium sulphate centrifugal

\footnotetext{
*Corresponding author, e-mail: nemanv10@area.ba.cnr.it
} 

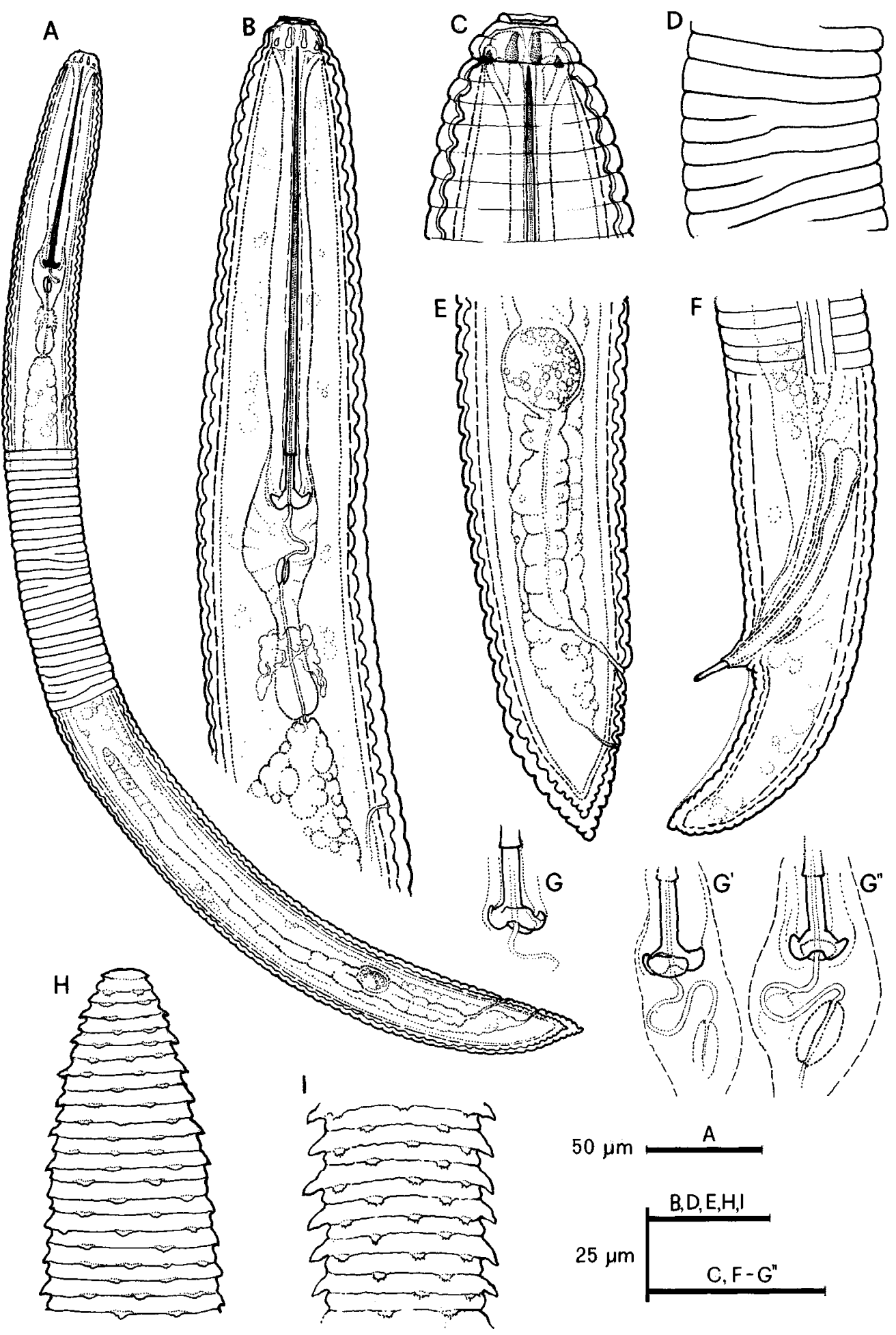

Fig. 1. Hemicriconemoides macrodorus n. sp. A: Entire female; B: Anterior body of female; C: Female anterior end; D: Anastomosed annuli; E: Posterior body of female; G-G": Stylet knobs patterns of females; $H, I$ : Fourth stage juvenile cuticular ornamentations at anterior and midbody. (Scale Bars: $A=50 \mu \mathrm{m} ; B, D, E, H, I=25 \mu \mathrm{m} ; C, F-G^{\prime \prime}=25 \mu \mathrm{m}$.) 

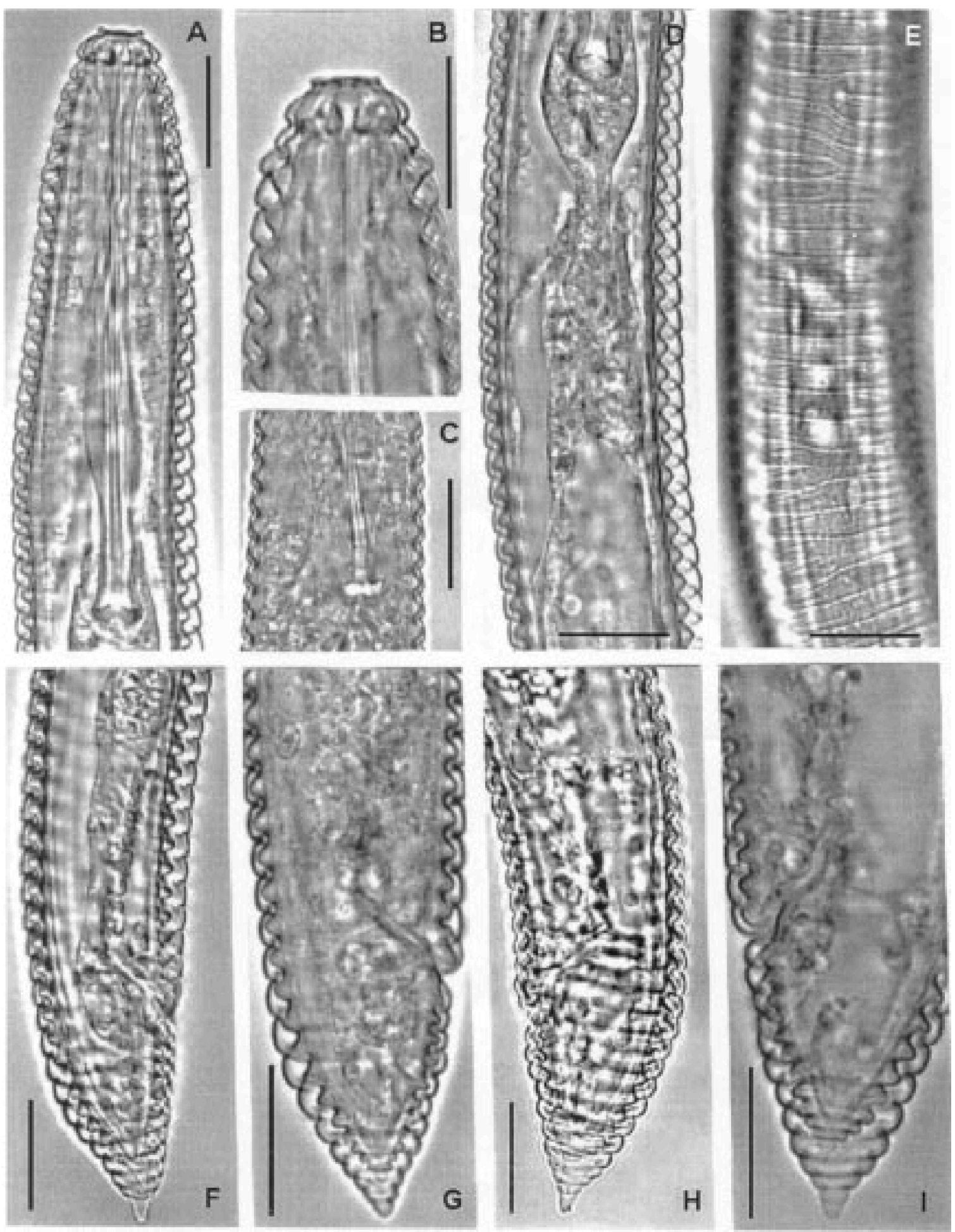

Fig. 2. Hemicriconemoides macrodorus $n$. sp. A: Anterior body of female; B: Female anterior end; $C$ : Body of female at level of stylet knobs; D: Female oesophagus and anterior end of intestine; E: Body annulation of female, showing anastomoses; F-I: Posterior body offemales. (Scale bars $=20 \mu \mathrm{m}$.) 

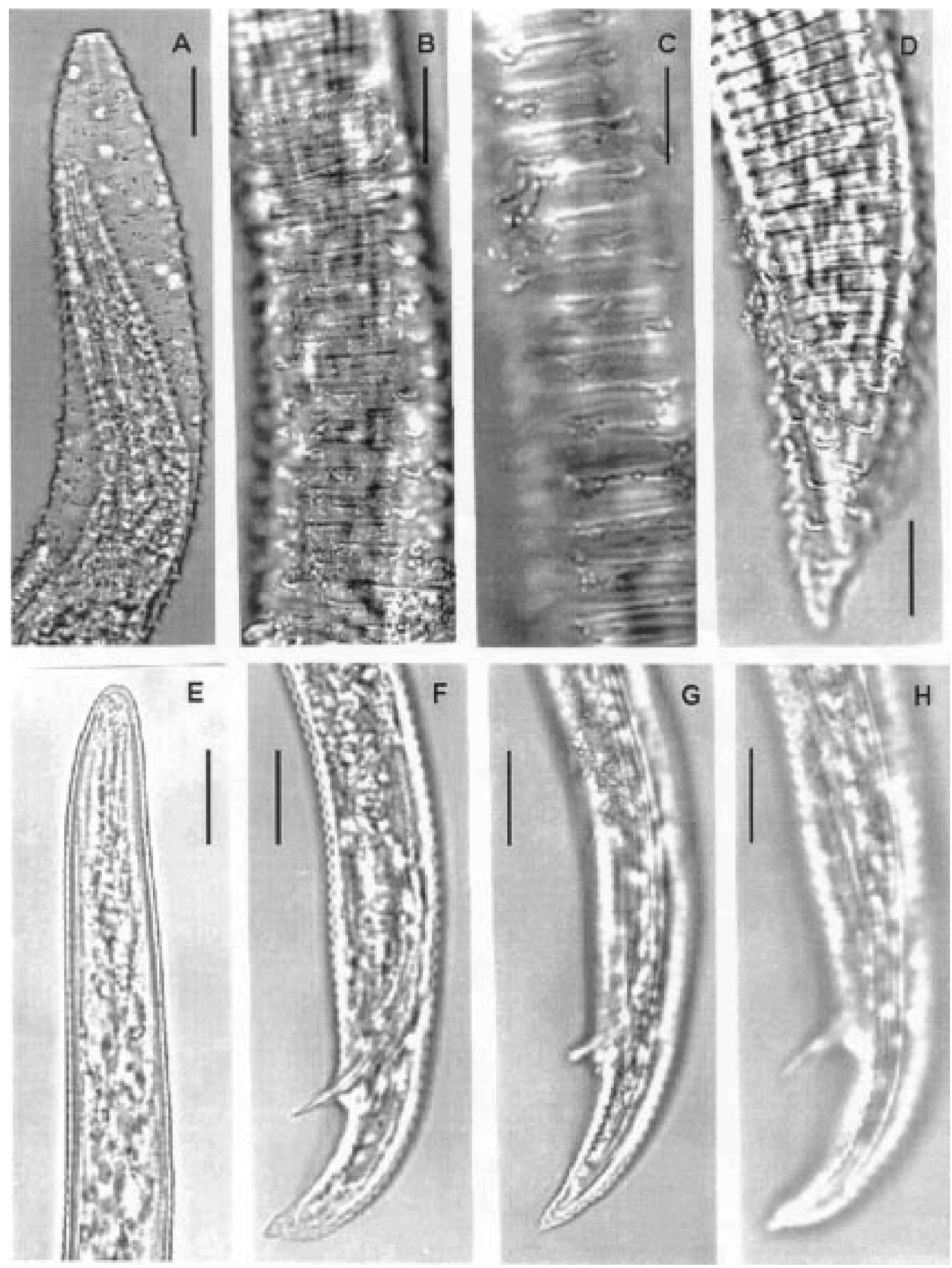

Fig. 3. Hemicriconemoides macrodorus $n$. sp. A: Anterior end of juvenile in moult; $B$-D: Body annulation of juvenile showing indented spines; E: Anterior body of male; F-H: Posterior body of male. (Scale bars $=20 \mu \mathrm{m}$.) 
flotation (Coolen, 1979). Specimens for light microscopy were killed by gentle heat, fixed in a solution of $4 \%$ formaldehyde $+1 \%$ propionic acid, and processed to pure glycerin with Seinhorst's (1966) method. Wergin's (1981) methods were used for the preparation of specimens for SEM observations, using an accelerating voltage 5-10 kV. Measurements were made using a camera lucida attachment to a light microscope.

\section{Hemicriconemoides macrodorus ${ }^{1}$ n. sp.} (Figs 1-3)

\section{MeAsurements}

See Table 1.

\section{DESCRIPTION}

\section{Female}

Body with curved posture when heat-relaxed, most of the body almost cylindrical, narrowing slightly at anterior and post-vulval portion. Cuticle with two discernible layers, fitting closely on anterior part of the body, well separated on tail. Annulation distinct on both cuticular layers. Anastomoses present, involving 0-14 annuli. Lip region with two distinct annuli. Lip sclerotisation massive. Stylet well developed, knobs with small anteriorly directed projections. Excretory pore located slightly posterior to pharyngo-intestinal junction. Reproductive system outstretched, extending for $242 \pm 70$ (201-346) $\mu \mathrm{m}$ or about $35 \%$ of body length. Spermatheca positioned 1322 annuli anterior to vulva, measuring $14 \times 21 \mu \mathrm{m}$. Body narrowing posteriorly to vulva. Post-vulval body region measuring 1-1.3 vulval body diam.; vulva and anus separated by five or six annuli. Tail tapering uniformly, curved dorsally, and ending with a rounded tip.

\section{Male}

Body straight or slightly curved. Lip region rounded. Body annuli very fine in anterior region, becoming coarser at mid-body. Stylet absent, pharynx degenerated. Hemizonid extending for two or three annuli, just anterior to excretory pore. Lateral field starting close to cephalic region, marked by four incisures. Caudal alae rudimentary, starting from cloaca and ending three or four annuli before

\footnotetext{
${ }^{1}$ The specific name refers to the primarily distinguishing character of the long stylet (from Greek, . , , s = long and $\because,=$ spear).
}

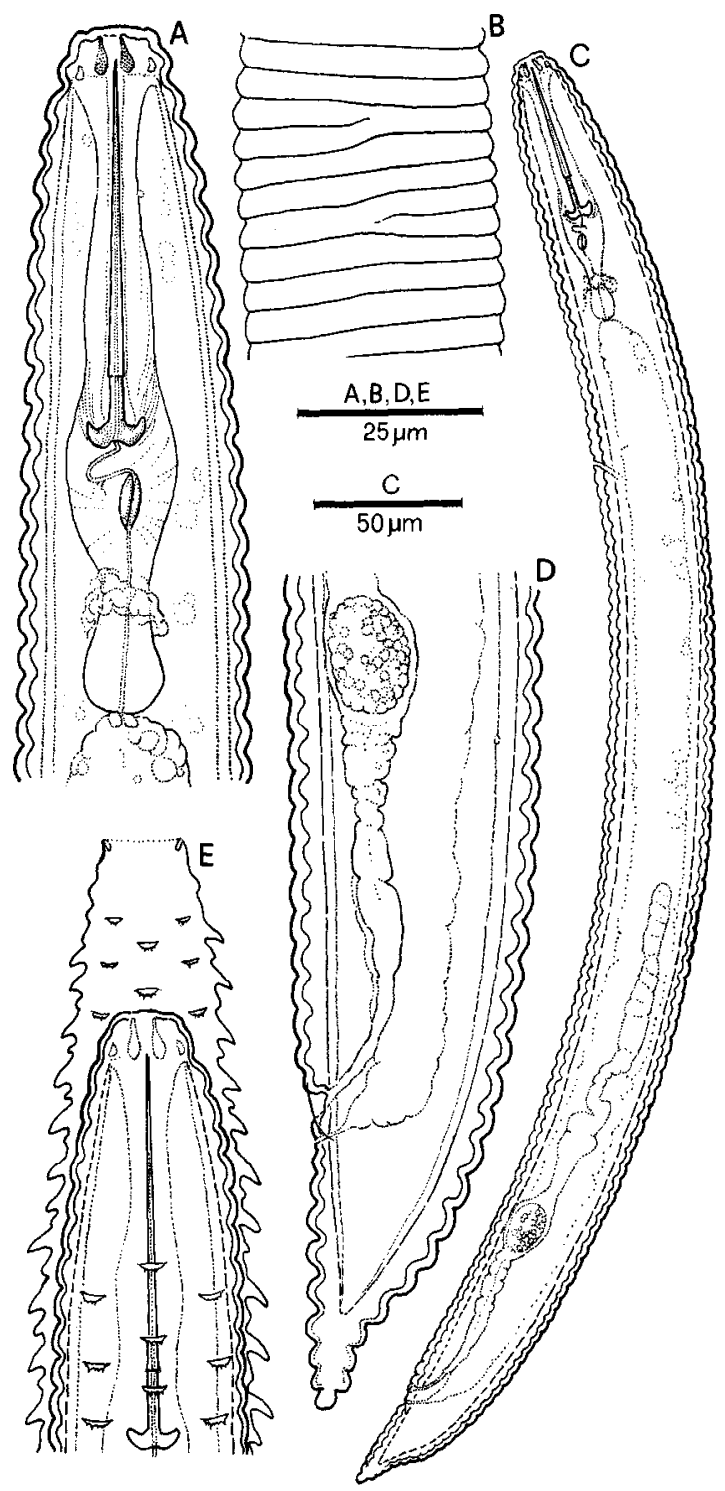

Fig. 4. Hemicriconemoides ortonwilliamsi. A: Anterior body female; B: Body annulation, with anastomoses; $C$ : Entire female; $D$ : Posterior body of female; E: Anterior body of moulting juvenile. (Scale bars: $A, B, D, E=25 \mu \mathrm{m} ; C=50 \mu \mathrm{m}$.)

terminus. Gonad packed with rounded sperm. Spicules slightly curved, cloacal tube short (3-4 $\mu \mathrm{m})$. Tail tapering with distinct annulation, dorsally curved terminus conoid.

\section{Juveniles}

Fourth stage juveniles resembling females in body posture, but differing from them in genital tract features, stylet length and cuticular ornamentation, their body, in 


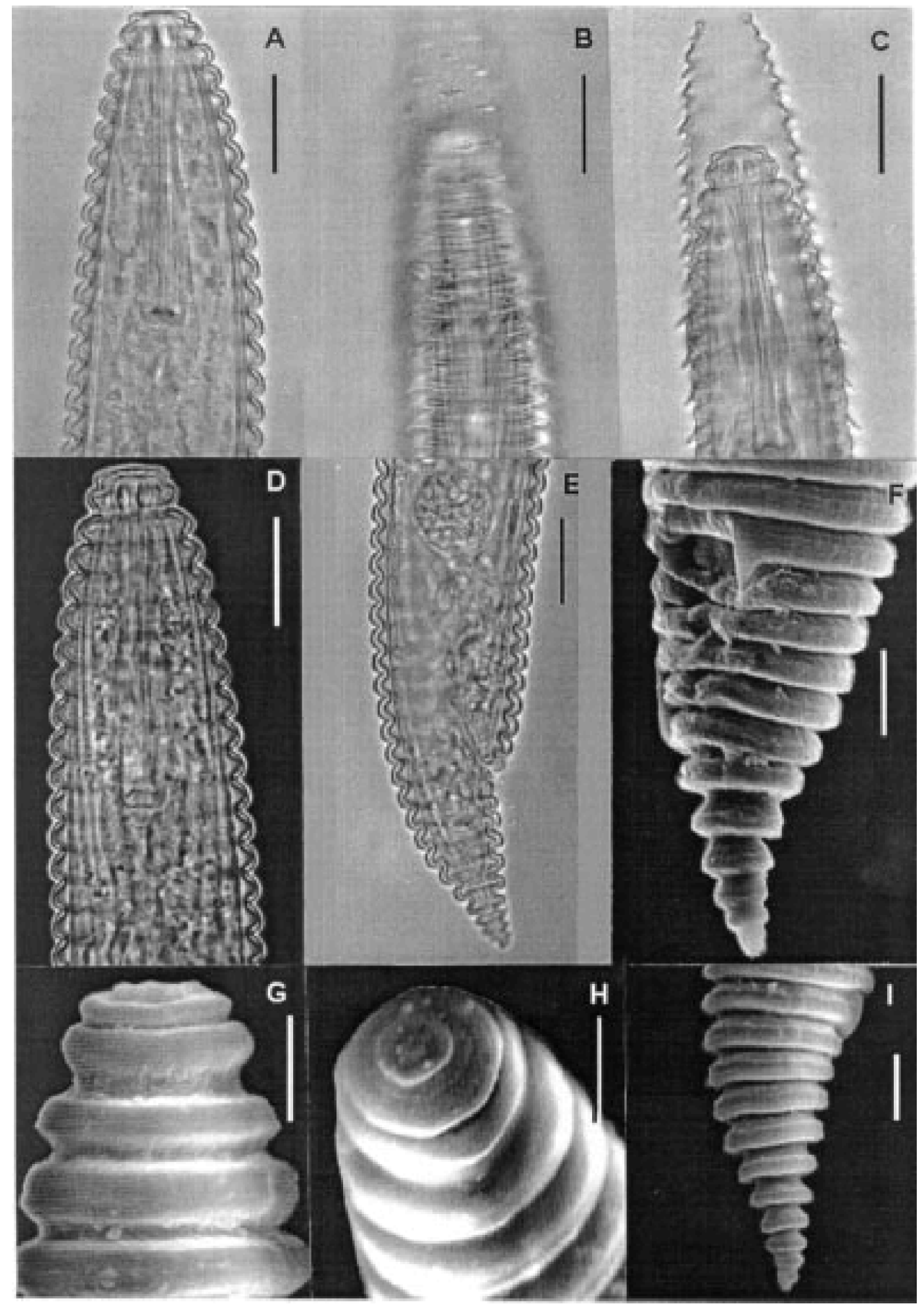

Fig. 5. Hemicriconemoides ortonwilliamsi. A, D: Anterior body of female; $B, C$ : Anterior body of juvenile, in moult; E: Posterior body of female; F, I: SEM micrographs of female tails; $G, H$ : SEM views of female anterior end. (Scale bars: $A-E=20 \mu \mathrm{m} ; F-I=10 \mu \mathrm{m}$.) 
fact, appearing distinctly ornamented by triangular scales, directed backwards, arranged in 10-12 rows at mid-body, alternating in position, bearing on their outer margins three to five indentations.

\section{TYPE HOST AND LOCALITY}

Holotype female, allotype male, and paratypes from soil samples collected in natural habitat at Santa Elena, Jaén, southern Spain, mainly from the rhizosphere of cork trees (Quercus suber L.) and several unidentified grasses and succulent plants.

\section{TYPE SPECIMENS}

Holotype (female), allotype (male), and additional paratypes deposited in the nematode collection at Istituto di Nematologia Agraria, CNR, Via Amendola, 165/A, 70126 Bari, Italy. Other paratype (females) deposited at University of California, Davis Nematode Collection, Davis, CA, USA; USDANC, Beltsville, MD, USA; Entomology and Nematology Department, Rothamsted Experimental Station, Harpenden, UK; Collection Nationale des Nématodes du Sol et Parasites de Plantes, IRD, Montpellier, France; Nematode Collection of Department of Nematology, Landbouwuniversiteit, Wageningen, The Netherlands; Koninklijk Belgisch Instituut voor Natuurwetenschappen, Brussel, Belgium.

\section{DIAGNOSIS AND RELATIONSHIPS}

Primary diagnostic features distinguishing Hemicriconemoides macrodorus $\mathrm{n}$. sp. are the truncate head shape, the very long stylet $90-110 \mu \mathrm{m}$, the lack of lateral cuticular vulval flaps, the vulva-anus distance, and the conical tail, curved dorsally. According to the species grouping of Decraemer and Geraert (1992), the new species belongs to 'group 2', which includes 13 other species (H. affinis, H. cocophillus, H. communis, H. intermedius, H. kanayensis, H. obtusus, H. ortonwilliamsi, H. pseudobrachyurum, $H$. rotundus, $H$. sacchariae, $H$. scottolamassesei, $H$. snoecki, and $H$. wessoni), characterised by a truncate lip region with the first lip annulus not differentiated. H. macrodorus $\mathrm{n}$. sp. is apparently similar to H. affinis Germani \& Luc 1970, H. cocophillus (Loos, 1949) Chitwood \& Birchfield, 1957, H. snoecki Van Doorsselaere \& Samsoen, 1982, and H. ortonwilliamsi. From these, $H$. macrodorus differs by a longer stylet (90-110 vs 50-57, 48-56, 49-57, 51-54 $\mu \mathrm{m}$, respectively), and a greater number of annuli between vulva and anus (5-6 vs 1-3, $1-2,1,1$, respectively).

\section{Hemicriconemoides ortonwilliamsi Ye \& Siddiqi, 1994 \\ (Figs 4, 5)}

\section{MEASUREMENTS}

See Table 1.

\section{REMARKS}

The Italian population was recovered from sandy soil samples collected from the rhizosphere of pine trees ( $P$ nus halepensis L.) in Pineto di Pescara, Italy, close to the

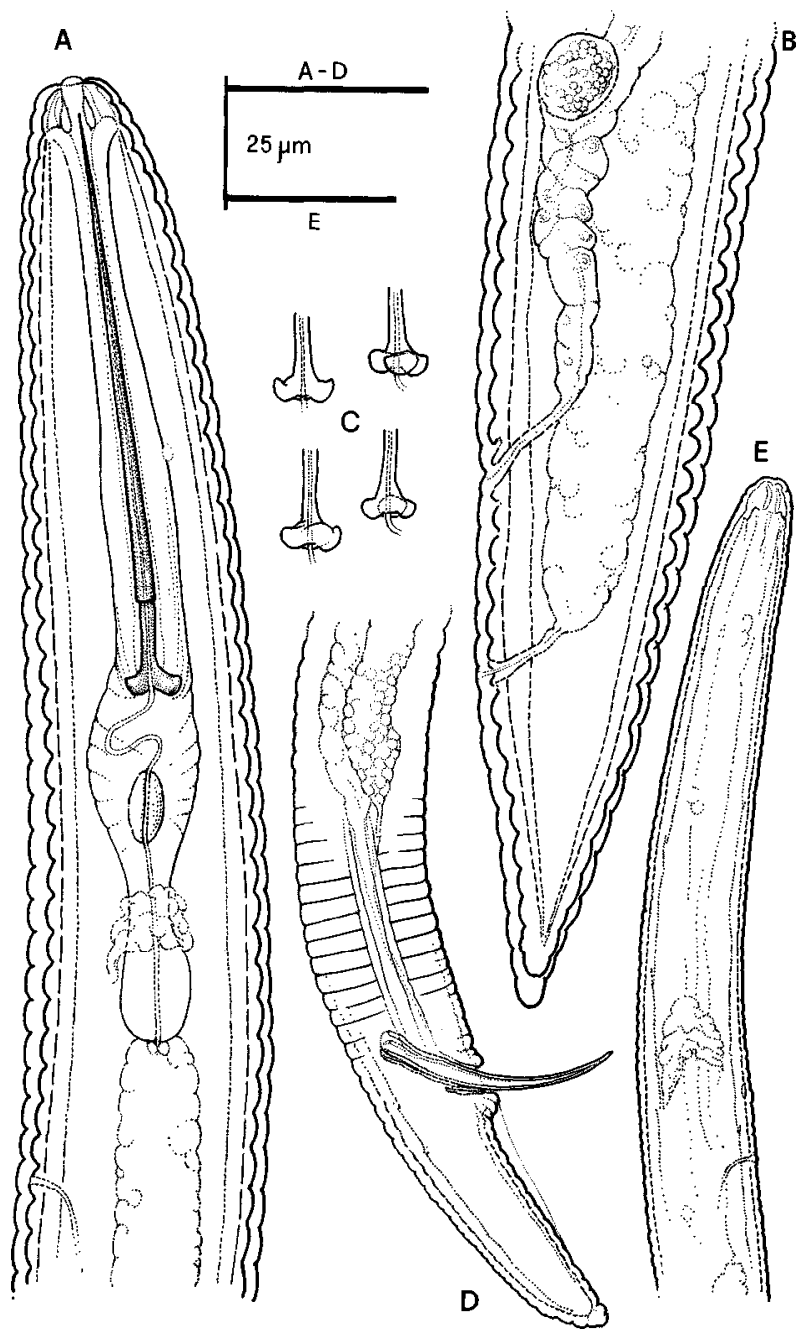

Fig. 6. Hemicriconemoides alexis. A: Anterior body of female; B: Posterior body of female; C: Stylet knobs; D: Posterior body of male; E: Anterior body of male. (Scale bars: $A-D=25 \mu \mathrm{m}$; $E=25 \mu \mathrm{m}$.) 

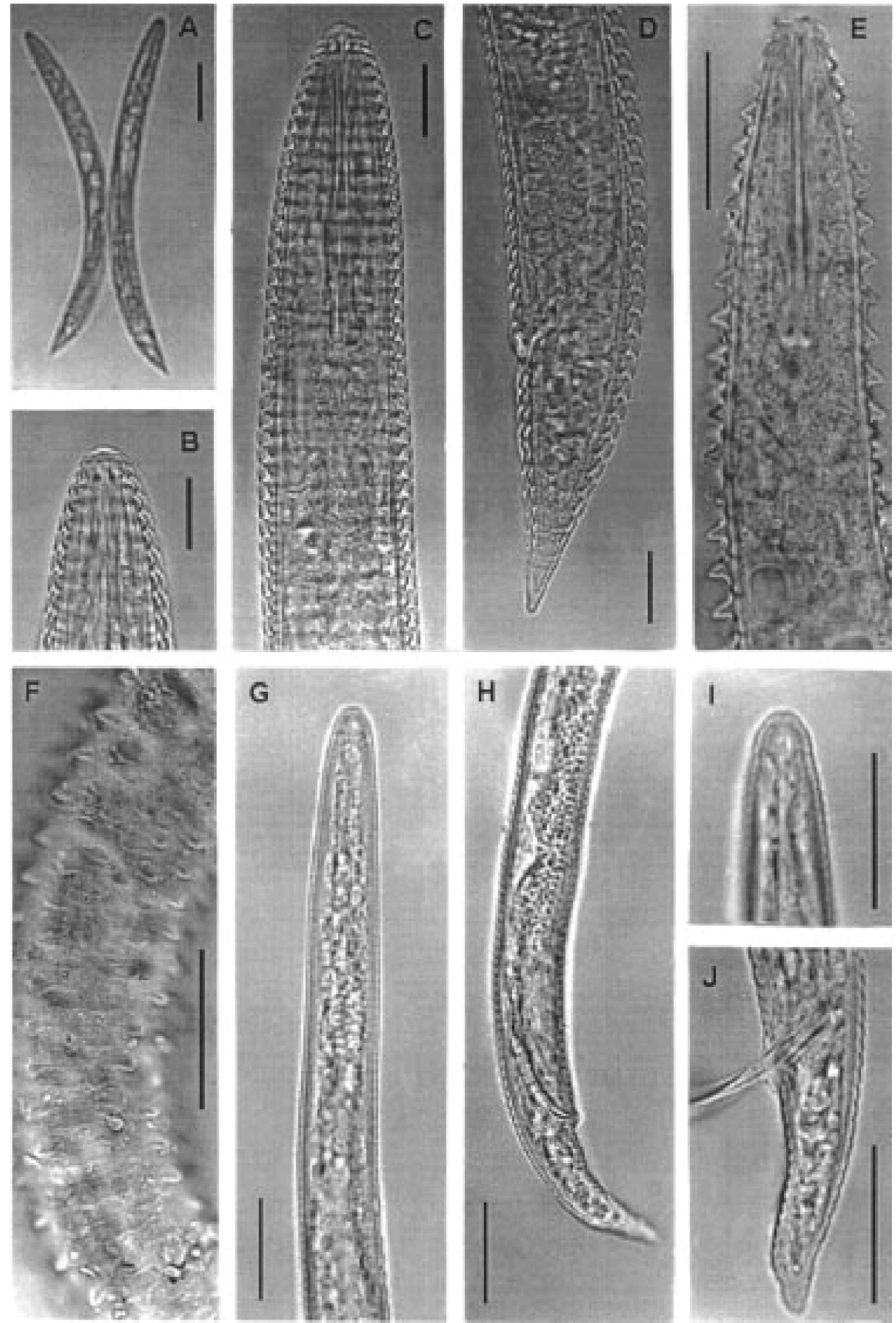

Fig. 7. Hemicriconemoides alexis. A: Female body posture; B: Female anterior end; C: Anterior body of female; D: Posterior body of female; E: Anterior body of juvenile; F: Body sheath of juvenile; G: Anterior body of male; H: Posterior body of male; I: Male anterior end; J: Male posterior end. (Scale bars: $A=100 \mu \mathrm{m} ; B-J=20 \mu \mathrm{m}$. ) 
Table 1. Morphometric data of Hemicriconemoides macrodorus $n$. sp., H. ortonwilliamsi, and H. alexis (all measurements in $\mu m$ ).

\begin{tabular}{|c|c|c|c|c|c|c|c|}
\hline & \multicolumn{4}{|c|}{ H. macrodorus } & \multirow{3}{*}{$\frac{\text { H. ortonwilliamsi }}{\text { Females }}$} & \multirow{2}{*}{\multicolumn{2}{|c|}{$\begin{array}{c}\text { H. alexis } \\
\text { Males }\end{array}$}} \\
\hline & \multicolumn{2}{|c|}{ Females } & \multicolumn{2}{|c|}{ Males } & & & \\
\hline & Holotype & Paratypes & Allotype & Paratypes & & Allotype & Topotypes \\
\hline $\mathrm{n}$ & & 26 & & 3 & 16 & & 5 \\
\hline $\mathrm{L}$ & 710 & $\begin{array}{r}691 \pm 46 \\
(548-761)\end{array}$ & 609 & $\begin{array}{c}606 \pm 12 \\
(593-616)\end{array}$ & $\begin{array}{l}514+24 \\
(477-552)\end{array}$ & 432 & $\begin{array}{l}422+18 \\
(394-441)\end{array}$ \\
\hline Max. body diam. & 43 & $\begin{array}{l}40 \pm 5 \\
(31-46)\end{array}$ & 20 & $\begin{array}{c}20.6 \pm 0.5 \\
(20-21)\end{array}$ & - & 22 & $\begin{array}{c}18+2.3 \\
(17-22)\end{array}$ \\
\hline Pharynx length & 140 & $\begin{array}{c}152 \pm 8 \\
(140-171)\end{array}$ & - & - & - & - & - \\
\hline $\begin{array}{l}\text { Ant. end/ } \\
\text { excret. pore }\end{array}$ & 187 & $\begin{array}{c}180 \pm 10 \\
(147-191)\end{array}$ & 146 & $\begin{array}{l}139 \pm 8.8 \\
(129-146)\end{array}$ & - & 102 & $\begin{array}{c}103+3.2 \\
(99-107)\end{array}$ \\
\hline Stylet & 100 & $\begin{array}{c}101 \pm 4.5 \\
(90-110)\end{array}$ & - & - & $\begin{array}{c}53+1.0 \\
(51-54)\end{array}$ & - & - \\
\hline $\begin{array}{l}\text { Stylet knobs } \\
\text { width }\end{array}$ & 9 & $\begin{array}{c}8.4 \pm 0.8 \\
\quad(7-10)\end{array}$ & - & - & - & - & - \\
\hline Tail length & 17 & $\begin{array}{c}16 \pm 3.8 \\
(13-22)\end{array}$ & 33 & $\begin{array}{c}34 \pm 0.6 \\
(32-34)\end{array}$ & - & 38 & $\begin{array}{c}39+2.8 \\
(35-42)\end{array}$ \\
\hline $\mathrm{R}^{1)}$ & 136 & $\begin{array}{c}137 \pm 6 \\
(127-148)\end{array}$ & - & - & $\begin{array}{c}105+3.9 \\
(99-111)\end{array}$ & - & - \\
\hline Rst & 22 & $\begin{array}{c}23 \pm 1.8 \\
(18-27)\end{array}$ & - & - & $\begin{array}{c}12+0.6 \\
(11-13)\end{array}$ & - & - \\
\hline Rphar & 29 & $\begin{array}{l}31 \pm 2.4 \\
(27-35)\end{array}$ & - & - & $\begin{array}{c}19+1.2 \\
(18-22)\end{array}$ & - & - \\
\hline $\operatorname{Rex}$ & 38 & $\begin{array}{c}37 \pm 2.2 \\
(31-41)\end{array}$ & - & - & $\begin{array}{c}26+2.2 \\
(23-28)\end{array}$ & - & - \\
\hline $\begin{array}{l}\text { RV from } \\
\text { terminus }\end{array}$ & 14 & $\begin{array}{c}13 \pm 0.7 \\
(12-14)\end{array}$ & - & - & $\begin{array}{c}11+0.9 \\
(10-12)\end{array}$ & - & - \\
\hline $\begin{array}{l}\text { Ran from } \\
\text { terminus }\end{array}$ & 8 & $\begin{array}{c}8 \pm 0.7 \\
(7-9)\end{array}$ & - & - & $\begin{array}{c}10+1.0 \\
(9-12)\end{array}$ & - & - \\
\hline RVan & 6 & $\begin{array}{c}4 \pm 0.7 \\
(5-6)\end{array}$ & - & - & 1 & - & - \\
\hline $\mathrm{V}$ or $\mathrm{T}$ & 95 & $\begin{array}{l}95 \pm 0.6 \\
(94-96)\end{array}$ & 26 & $\begin{array}{c}33 \pm 6.5 \\
(26-39)\end{array}$ & - & 36 & $\begin{array}{c}36+1.5 \\
(34-38)\end{array}$ \\
\hline $\mathrm{St} \% \mathrm{~L}$ & 14 & $\begin{array}{l}15 \pm 1.1 \\
(13-18)\end{array}$ & - & - & - & - & - \\
\hline St $\%$ pharynx ${ }^{2)}$ & 71 & $\begin{array}{l}62 \pm 11 \\
(53-72)\end{array}$ & - & - & - & - & - \\
\hline $\mathrm{a}$ & 16 & $\begin{array}{c}17 \pm 2.4 \\
(15-21)\end{array}$ & 30 & $\begin{array}{c}29 \pm 1.0 \\
(28-30)\end{array}$ & $\begin{array}{c}15+1.4 \\
(13-17)\end{array}$ & 20 & $\begin{array}{c}23+2.5 \\
(20-26)\end{array}$ \\
\hline $\mathrm{b}$ & 5 & $\begin{array}{l}4.4 \pm 0.4 \\
(3.8-5.2)\end{array}$ & - & - & $\begin{array}{l}5.5+0.3 \\
(5.1-5.9)\end{array}$ & - & - \\
\hline $\mathrm{c}$ & 41 & $\begin{array}{c}42 \pm 7.2 \\
(31-56)\end{array}$ & 18 & $\begin{array}{c}18 \pm 0 \\
(18)\end{array}$ & $\begin{array}{c}17+1.5 \\
(16-19)\end{array}$ & 11 & $\begin{array}{c}11+0.5 \\
(10-11)\end{array}$ \\
\hline $\mathrm{c}^{\prime}$ & - & - & - & - & - & 2.5 & $\begin{array}{l}2.8+0.3 \\
(2.5-3.2)\end{array}$ \\
\hline $\mathrm{VL} / \mathrm{VB}^{3)}$ & 1.0 & $\begin{array}{l}1.2 \pm 0.2 \\
(0.8-1.3)\end{array}$ & - & - & $\begin{array}{l}1.5+0.5 \\
(1.4-1.6)\end{array}$ & - & - \\
\hline $\mathrm{VL} / \mathrm{St}$ & 0.4 & $\begin{array}{l}0.3 \pm 0.1 \\
(0.2-0.4)\end{array}$ & - & - & - & - & - \\
\hline
\end{tabular}


Table 1. (Continued).

\begin{tabular}{|c|c|c|c|c|c|c|c|}
\hline & \multicolumn{4}{|c|}{ H. macrodorus } & \multirow{3}{*}{$\frac{\text { H. ortonwilliamsi }}{\text { Females }}$} & \multirow{2}{*}{\multicolumn{2}{|c|}{$\frac{\text { H. alexis }}{\text { Males }}$}} \\
\hline & \multicolumn{2}{|c|}{ Females } & \multicolumn{2}{|c|}{ Males } & & & \\
\hline & Holotype & Paratypes & Allotype & Paratypes & & Allotype & Topotypes \\
\hline $\begin{array}{l}\text { Spermatheca } \\
\text { diam. }\end{array}$ & - & - & - & - & $\begin{array}{c}14.5+2.9 \\
(12-17)\end{array}$ & - & - \\
\hline $\begin{array}{l}\text { Annuli average } \\
\text { width }\end{array}$ & 5.8 & $\begin{array}{l}5.4 \pm 0.4 \\
(4.5-6.2)\end{array}$ & - & - & $5^{4)}$ & 1.8 & $\begin{array}{c}1.8-0.2 \\
(1.6-2.0)\end{array}$ \\
\hline Anal body diam. & 19 & $\begin{array}{l}17 \pm 3.5 \\
(13-22)\end{array}$ & 14.5 & $\begin{array}{l}15 \pm 0.8 \\
(14.5-16)\end{array}$ & - & 15 & $\begin{array}{c}14+1.1 \\
(13-15)\end{array}$ \\
\hline $\begin{array}{l}\text { Lateral field } \\
\text { width }\end{array}$ & - & - & 4.3 & $\begin{array}{c}4.5 \\
(4.3-4.6)\end{array}$ & - & 3.2 & $\begin{array}{l}3.2+0.7 \\
(3.0-3.7)\end{array}$ \\
\hline Spicules & - & - & 32 & $\begin{array}{c}36 \pm 3.5 \\
(32-39)\end{array}$ & - & 31 & $\begin{array}{c}32+0.7 \\
(31-33)\end{array}$ \\
\hline Gubernaculum & - & - & 6 & $\begin{array}{l}6 \pm 0 \\
(6)\end{array}$ & - & 6 & $\begin{array}{c}6+0.5 \\
(6-7)\end{array}$ \\
\hline
\end{tabular}

${ }^{1)} \mathrm{R}=$ number $(\mathrm{n}$.) of body annuli on the ventral side of the body; Rst = n. of body annuli opposite the stylet; Rphar = n. of body annuli opposite the pharynx; Rex $=\mathrm{n}$. of annuli from the anterior end to the excretory pore; RV $=\mathrm{n}$. of body annuli between the vulva and the tail terminus; Rvan $=\mathrm{n}$. of body annuli between vulva and anus; Ran $=\mathrm{n}$. of body annuli between the anus and tail terminus ( after De Grisse, 1964);

2) ST\%pharynx = ratio, stylet length as percentage of the pharynx length. All other abbreviations used are defined in Siddiqi (1986).

3) $\mathrm{VL} / \mathrm{VB}=$ ratio, post-vulval length divided by the body width at the vulva; ST\%L = ratio, stylet length as a percentage of the total body length;

4) Maximum width.

Adriatic coast. The specimens (only females and juveniles were collected) of the present population agree very well with the original type material from Samoa Isles, described by Ye and Siddiqi (1994), although small differences in greater number of body annuli (99-101 vs 8698), Rs (18-22 vs 15-19); and smaller stylet (51-54 vs 52$64 \mu \mathrm{m}$ ), were detected. Our report extends the distribution of this species, including a Mediterranean country and is the first detection since the original description.

\section{VOUCHER SPECIMENS}

All specimens in glycerin on permanent slides are deposited in the nematode collection of Istituto di Nematologia Agraria CNR, Bari, Italy.

\section{Hemicriconemoides alexis Vovlas, 1980 (Figs 6, 7)}

\section{DESCRIPTION}

\section{Male}

Body straight or slightly curved. Lip region rounded. Body annuli very fine in anterior region, becoming coarser at mid-body. Stylet absent, pharynx degenerate. Hemizonid extending over two annuli, three to four annuli anterior to excretory pore. Lateral field starting close to lip region, marked by four incisures. Caudal alae rudimentary, beginning from cloaca and ending five or six annuli before tail terminus. Gonad 151 (146-158) $\mu \mathrm{m}$ long, packed with rounded sperm. Spicules slightly curved, cloacal tube short $(2-3 \mu \mathrm{m})$. Tail tapering, distinctly annulated, with dorsally curved conoid terminus.

\section{Juveniles}

Fourth stage juveniles resembling females in body posture, but differing from them in genital tract development, stylet length and cuticular ornamentation. Body ornamented by triangular scales, directed backwards, arranged in 10-12 rows at mid-body, alternating in position, bearing on their outer margins three to five indentations in some cases, or smooth in others.

See Table 1. 


\section{VOUCHER SPECIMENS}

All males on glass slides are deposited in the nematode collection of Istituto di Nematologia Agraria, CNR, Bari, Italy.

\section{Acknowledgements}

The authors are grateful to Prof. Dr W. Decraemer (Brussel, Belgium) for her helpful comments and valuable suggestions in revising the manuscript.

\section{References}

Chitwood, B.G. \& Birchfield, W. (1957). A new genus, Hemicriconemoides (Criconematidae: Tylenchina). Proceedings of the Helminthological Society of Washington 24, 80-86.

Coolen, W.A. (1979). Methods for extraction of Meloidogyne spp. and other nematodes from roots and soil. In: Lamberti, F. \& Taylor, C.E. (Eds). Root-knot nematodes (Meloidogyne species). Systematics, biology and control. New York, NY, USA, Academic Press, pp. 317-329.

DeCrAemer, W. \& Geraert E. (1992). Description of Hemicriconemoides parataiwanensis sp. n. (Criconematidae) and four other Hemicriconemoides species from Papua New Guinea with a consideration of variability in the genus. $\mathrm{Ne}$ matologica 38, 267-295.

DE GRISSE, A.T. (1964). Morphological observations on Criconemoides, with description of four new species found in Belgium (Nematoda). Mededelingen van de Landbouwhogeschool en de Opzoekingsstations van de Staat te Gent, 29: 734-761.
EBSARY, B.A. (1991). Catalog of the order Tylenchida (Nematoda). Ottawa, Ontario, Canada. Research Branch Agriculture Canada, Publication 1869/B 1991, Minister of Supply and Service Canada, 196 pp.

Germani, G. \& LuC, M. (1970). Contribution à l'étude du genre Hemicriconemoides Chitwood \& Birchfield, 1957 (Nematoda: Criconematidae). Cahiers ORSTOM, Série Biologie 11, 134-150.

Loos, C.A. (1949). Notes on free-living and plant-parasitic nematodes of Ceylon - No 4. Journal of the Zoological Society of India 1, 17-22.

RAHAMAN, P.F. \& AHMAD, I. (1995). Hemicriconemoides variabilis sp. n. and two known species of Hemicriconemoides from India. Nematologia Mediterranea 23, 203-210.

SEINHORST, J.W. (1966). Killing nematodes for taxonomic study with hot f.a. $4: 1$. Nematologica 12, 178.

SIDDIQI, M.R. (1986). Tylenchida. Parasites of plants and insects. Wallingford, UK, CAB International, $v+645$ p.

VAn Doorsselaere, R. \& Samsoen, L. (1982). Some tylenchids from coffee-fields of Ivory Coast, with the description of Hemicriconemoides snoecki n.sp. (Nematoda: Tylenchida). Revue de Nématologie 5, 51-63.

Vovlas, N. (1980). Two new sheathoid nematodes (Nematoda: Criconematidae) from the Mediterranean region. Nematologia Mediterranea 8, 73-79.

WERGIN, W.P. (1981). Scanning electron microscopic techniques and application for use in Nematology. In: Zuckerman, B.Z. \& Rohde, R.A. (Eds). Plant-parasitic nematodes. Vol. 3. New York, NY, USA, Academic Press, pp. 175-204.

Ye, W. \& SiddiQI, M.R. (1994). Two new species of Hemicriconemoides (Nematoda: Criconematidae) from South $\mathrm{Pa}$ cific with notes on four other known species. Afro-Asian Journal of Nematology 4, 215-223. 